\title{
HUBUNGAN EKSKRESI ALBUMINURIA DENGAN PENYAKIT JANTUNG HIPERTENSI DI BLU/RSUP Prof. dr. R.D. Kandou MANADO NOVEMBER - DESEMBER 2012
}

\author{
${ }^{1}$ Robert M. Biseph \\ ${ }^{2}$ A. Lucia Panda \\ ${ }^{2}$ Eko E. Surachmanto \\ ${ }^{1}$ Kandidat Skripsi Fakultas Kedokteran Universitas Sam Ratulangi Manado \\ ${ }^{2}$ Bagian Ilmu Penyakit Dalam BLU RSU Prof. dr. R.D. Kandou Manado
}

Latar Belakang: Penyakit jantung hipertensi merupakan penyakit kardiovaskular yang disebabkan oleh tekanan darah tinggi yang berlangsung kronis dan berhubungan dengan hipertrofi ventrikel kiri dan disfungsi endotel. Kejadian albuminuria pada penderita hipertensi berhubungan dengan kerusakan endotel glomerulus dan merupakan prediktor penyakit kardiovaskular. Penelitian ini bertujuan untuk menilai hubungan antara ekskresi albuminuria dengan penyakit jantung hipertensi berdasarkan derajat penyakit menurut NYHA. Metode: Penelitian ini menggunakan desain cross sectional. Subjek penelitian adalah pasien penyakit jantung hipertensi (PJH) yang di rawat di BLU/RSUP Prof. dr. R.D.Kandou Manado yang berjumlah 20 pasien dengan derajat ringan dan 20 pasien dengan derajat berat. Pengukuran variabel berdasarkan catatan pada rekam medik pasien, anamnesis dan pengukuran albuminuria dengan menggunakan dipstick. Hasil: Uji chi-square menunjukan bahwa terdapat hubungan yang bermakna antara ekskresi albuminuria dengan penyakit jantung hipertensi $(\mathrm{p}=0,001)$ dengan nilai prediksi OR pada CI 95\% (2,27-48,75) ialah 10,52. Tidak terdapat hubungan antara umur dengan ekskresi albuminuria $(\mathrm{p}=0,799)$, jenis kelamin dengan ekskresi albuminuria $(\mathrm{p}=0,121)$. Kesimpulan: Dari hasil penelitian ini kejadian albuminuria berhubungan dengan penyakit jantung hipertensi dimana terjadi peningkatan resiko ekskresi albuminuria pada pasien $\mathrm{PJH}$ dengan derajat berat dibandingkan dengan pasien PJH dengan derajat ringan.

Kata Kunci: Albuminuria, Penyakit Jantung Hipertensi

\section{LATAR BELAKANG}

Hipertensi merupakan masalah kesehatan masayrakat, hipertensi didefinisikan sebagai peningkatan tekanan darah sistolik sedikitnya $140 \mathrm{mmHg}$ atau tekanan diastolik sedikitnya 90 mmHg. ${ }^{1}$ Hipertensi yang tidak terkontrol dapat memicu timbulnya penyakit degeneratif, seperti gagal jantung kongestif, gagal ginjal, dan penyakit vaskuler. Dalam perjalanannya, Hipertensi dapat mengakibatkan gangguan pada jantung, otak, ginjal, dan mata melalui dua mekanisme yang berhubungan yaitu efek dari peningkatan tekanan arteri (pada struktur serta fungsi jantung dan arteri) dan efek dalam percepatan perkembangan aterosklerosis. ${ }^{2}$

Di Asia tercatat 38,4 juta penderita hipertensi pada tahun 2000 dan meningkat menjadi 67,4 juta orang pada tahun 2005. Menurut Survei Kesehatan Rumah Tangga (SKRT) di Indonesia tahun 1995, prevalensi hipertensi untuk penduduk berumur $>25$ tahun adalah 8,3\%, dengan prevalensi pada laki-laki sebesar 7,4\% dan pada perempuan sebesar 9,1\%. Berdasarkan 
SKRT tahun 2004, prevalensi hipertensi di Indonesia sebesar 14\%, dengan prevalensi laki-laki sebesar $12,2 \%$ dan perempuan 15,5\%. Penyakit sistem sirkulasi dari hasil SKRT tahun 1992, 1995, dan 2001 selalu menduduki peringkat pertama dengan prevalensi terus meningkat yaitu $16 \%, 18,9 \%$, dan $26,4 \% .^{3}$

Di Indonesia prevalensi hipertensi cukup tinggi, meskipun tidak setinggi di negara-negara yang sudah maju, sedangkan WHO memperkirakan bahwa $20 \%$ dari umat manusia yang berusia dewasa muda menderita hipertensi. ${ }^{4}$

Penyakit jantung hipertensi merupakan salah satu penyakit kardiovaskuler, dimana penyebabnya adalah tekanan darah tinggi yang berlangsung kronis, namun penyebab tekanan darah tinggi dapat beragam. Essensial hipertensi menyumbang 90\% dari kasus hipertensi pada orang dewasa, hipertensi sekunder berjumlah $10 \%$ dari sisa kasus kronis hipertensi. ${ }^{5}$

Hipertensi tak terkontrol dan berkepanjangan dapat menyebabkan berbagai perubahan dalam struktur miokard, pembuluh darah koroner, dan sistem konduksi jantung. Perubahan ini pada gilirannya dapat menyebabkan perkembangan hipertrofi ventrikel kiri (LVH), penyakit arteri koroner (CAD), berbagai penyakit sistem konduksi, serta disfungsi sistolik dan diastolik dari miokardium, yang bermanifestasi klinis sebagai angina atau infark miokard, aritmia jantung (terutama fibrilasi atrium), dan gagal jantung kongestif (CHF). Dengan demikian, penyakit jantung hipertensi adalah istilah yang diterapkan secara umum untuk penyakit jantung, seperti $\mathrm{LVH}$, penyakit arteri koroner, aritmia jantung, dan $\mathrm{CHF}$, yang disebabkan oleh efek langsung atau tidak langsung dari hipertensi. ${ }^{6}$

Pada gagal jantung kongestif yang disertai peningkatan tekanan vena dapat menyebabkan pengeluaran albumin melalui saluran cerna secara langsung dengan proses perembesan cairan dari permukaan mukosa usus. ${ }^{7}$

Keluarnya albumin melalui urine adalah karena peningkatan permeabilitas di tingkat glomerulus yang menyebabkan protein lolos ke dalam filtrat glomerulus. Konsentrasi protein ini melebihi kemampuan sel-sel tubulus ginjal mereabsopsi dan memprosesnya. Pola protein dalam urine bersifat komplementer dengan pola yang terdapat dalam serum pasien, dengan albumin merupakan protein terbanyak dalam urine. ${ }^{7}$

Albumin adalah salah satu protein plasma terkecil $(69 \mathrm{kDa})$ dan yang utama dalam plasma manusia $(3,4-4,7 \mathrm{~g} / \mathrm{dL})$ dan membentuk sekitar $60 \%$ protein plasma total. Sekitar $40 \%$ albumin terdapat dalam plasma, dan sisanya $60 \%$ sisanya terdapat di ruang ekstrasel. ${ }^{8}$

Berdasarkan fakta-fakta statistik di atas, maka penulis tertarik untuk mengadakn penelitian guna mengetahui Hubungan Antara Ekskresi Albumin Urin dengan Penyakit Jantung Hipertensi yang dirawat di Bagian Ilmu Penyakit Dalam BLU RSUP. Prof. dr. R.D. Kandou Manado.

\section{METODOLOGI PENELITIAN}

Penelitian yang dilakukan adalah penelitian deskriptif analitik dengan pendekatan cross sectional. Penelitian dilaksanakan pada bulan November sampai bulan Desember 2012 dengan lokasi penelitian di Poli Jantung, Irina F, dan CVCU BLU RSUP. Prof. dr. R.D. Kandou Manado pada seluruh pasien gagal jantung e.c penyakit jantung hipertensi berusia 40 sampai 70 tahun yang masukdan dirawat di Bagian Ilmu penyakit Dalam BLU RSUP Prof. R.D. Kandou Manado Periode November - Desember 2012. Sampel penelitian ini diseleksi berdasarkan data rekam medik pasien dan pemeriksaan urin pada sampel menggunakan dipstick.

\section{HASIL PENELITIAN Data Deskriptif}


Dari hasil penelitian yang dilakukan di Poliklinik Jantung, Ruang Irina F Jantung, dan CVCU BLU RSUP Prof. dr. R.D. Kandou Manado pada periode bulan November sampai Desember 2012, didapat 40 sampel dengan hasil sebagai berikut.

1. Kategori jenis kelamin

Tabel 1 : Distribusi frekuensi jenis kelamin

\begin{tabular}{lll}
\hline & Frekuensi & Persentase (\%) \\
\hline Laki-laki & 21 & 52,5 \\
Perempuan & 19 & 47,5 \\
\hline Total & 40 & 100,0 \\
\hline
\end{tabular}

Dalam tabel 1, terdapat frekuensi laki-laki dalam sampel yaitu $21(52,5 \%)$ orang sedangkan perempuan $37(47,5 \%)$ orang.

2. Jumlah kategori umur

Tabel 2 : Distribusi frekuensi umur

\begin{tabular}{lll}
\hline & Frekuensi & Persentase $(\%)$ \\
\hline $\mathbf{4 0}-\mathbf{4 9}$ tahun & 5 & 12,5 \\
$\mathbf{5 0}-\mathbf{5 9}$ tahun & 13 & 32,5 \\
$\mathbf{6 0}-\mathbf{7 0}$ tahun & 22 & 55,0 \\
\hline Total & 40 & 100,0 \\
\hline
\end{tabular}

Dalam tabel 2, usia sampel yang masuk dalam kategori usia 40-49 tahun ada $5(12,5 \%)$ sampel dan yang masuk kategori usia 50-59 tahun berjumlah 13 (32,5\%) sampel dan yang masuk kategori usia 60-70 tahun berjumlah 22 (55,0\%) sampel.

3. Jumlah pasien Penyakit Jantung Hipertensi (PJH)

Tabel 3 : Distribusi frekuensi pasien PJH menurut derajat penyakit

\begin{tabular}{lll}
\hline & Frekuensi & Persentase (\%) \\
\hline $\begin{array}{l}\text { Derajat Ringan } \\
\text { (CHF I dan II) }\end{array}$ & 20 & 50,0 \\
$\begin{array}{l}\text { Derajat Berat } \\
\text { (CHF III dan IV) }\end{array}$ & 20 & 50,0 \\
\hline Total & 40 & 100,0 \\
\hline
\end{tabular}

Dalam tabel 3, terdapat 20 (50\%) sampel dengan derajat ringan (CHF I dan II), dan 20 (50\%) dengan derajat berat (CHF III dan IV).

4. Kadar albumin urin

Tabel 4 : Distribusi frekuensi kadar albumin urin

\begin{tabular}{lll}
\hline & Frekuensi & Persentase (\%) \\
\hline Negatif & 16 & 40 \\
Positif & 24 & 60 \\
\hline Total & 40 & 100,0 \\
\hline
\end{tabular}


Dalam tabel 4, terdapat $16(40 \%)$ sampel memiliki kadar albumin dalam urin yang negatif atau $<30 \mathrm{mg} / \mathrm{dl}$, dan yang memiliki kadar albumin dalam urin positif yaitu 24 (60\%) sampel.

\section{Data Analitik}

1. Hubungan klasifikasi perawatan berdasarkan diagnosis dengan kadar albumin urin pasien PJH Tabel 5 : Hubungan kadar albumin urin dengan PJH pada derajat ringan dan derajat berat

\begin{tabular}{|c|c|c|c|c|c|c|}
\hline & \multicolumn{2}{|c|}{ Kadar albumin urin } & \multirow{2}{*}{ Total } & \multirow{2}{*}{$\begin{array}{l}\text { Nilai } \\
\text { p }\end{array}$} & \multirow{2}{*}{$\begin{array}{l}\text { Prediksi } \\
\text { OR }\end{array}$} \\
\hline & & Negatif & Positif & & & \\
\hline \multirow{7}{*}{$\begin{array}{l}\text { Derajat } \\
\text { Penyakit } \\
\text { Jantung } \\
\text { Hipertensi }\end{array}$} & & 13 & 7 & 20 & \multirow[b]{5}{*}{0,001} & \multirow{7}{*}{$\begin{array}{l}10,52 \\
\text { pada } \\
\text { CI 95\% } \\
(2,27- \\
48,75)\end{array}$} \\
\hline & $\begin{array}{l}\text { Derajat Ringan } \\
\text { (CHF I dan II) }\end{array}$ & $65,0 \%$ & $35,0 \%$ & $50,0 \%$ & & \\
\hline & & & & & & \\
\hline & \multirow{2}{*}{$\begin{array}{l}\text { Derajat Berat } \\
\text { (CHF III dan IV) }\end{array}$} & & & & & \\
\hline & & $15,0 \%$ & $85,0 \%$ & $50,0 \%$ & & \\
\hline & & 16 & 24 & 40 & & \\
\hline & Total & $40,0 \%$ & $60,0 \%$ & 100,0 & & \\
\hline
\end{tabular}

Dalam tabel 5, menunjukkan bahwa 13 sampel PJH dengan derajat ringan memiliki kadar albumin urin negatif dan 7 sampel memiliki kadar albumin urin positif, sedangkan sampel PJH dengan derajat berat yang memiliki kadar albumin negatif adalah 3 sampel dan yang positif 17 sampel. Nilai $\mathrm{p}=0,001$ menunjukkan bahwa dalam penelitian ini terdapat hubungan yang signifikan/bermakna antara ekskresi albumin urin dengan penyakit jantung hipertensi. Nilai prediksi OR pada CI 95\% (2,27-48,75) ialah 10,52 artinya jika dilakukan penelitian selanjutnya bisa ditemukan bahwa penderita penyakit jantung hipertensi berisiko meningkatkan kadar albumin dalam urin sebesar 10,52 kali apabila variabel lain dikontrol. Nilai rasio prevalensi pada penelitian ini sebesar 4,33.

2. Hubungan umur dengan kadar albumin urin pada pasien $\mathrm{PJH}$

Tabel 6 : Hubungan umur dengan kadar albumin urin

\begin{tabular}{llcccc}
\hline & & \multicolumn{2}{c}{ Kadar albumin urin } & \multirow{2}{*}{ Total } & Nilai \\
\cline { 3 - 4 } & & Negatif & Positif & & p \\
\hline \multirow{3}{*}{$\begin{array}{l}\text { Kategori } \\
\text { umur }\end{array}$} & $\mathbf{5 0}-\mathbf{5 9}$ tahun & 0 & 5 & 5 & \\
& & $0,0 \%$ & $12,5 \%$ & $12,5 \%$ & 0,799 \\
& $\mathbf{6 0}-\mathbf{7 0}$ tahun & 7 & 6 & 13 & \\
& & $17,5 \%$ & $15,0 \%$ & $32,5 \%$ & \\
& Total & 9 & 13 & 22 & \\
& & $22,5 \%$ & $32,5 \%$ & $55,0 \%$ & \\
& & 16 & 24 & 66 & \\
\hline
\end{tabular}

Dalam tabel 6, menunjukkan bahwa sampel dengan kategori usia 40 - 49 tahun tidak terdapat $(0,0 \%)$ sampel dengan kadar albumin urin negatif dan $5(12,5 \%)$ sampel dengan kadar albumin urin positif. Pada kategori usia 50 - 59 tahun terdapat 7 (17,5\%) sampel dengan kadar albumin 
urin negatif dan $6(15,0 \%)$ sampel dengan kadar positif. Pada kategori usia 60 - 70 tahun terdapat $9(22,5 \%)$ sampel dengan kadar albumin urin negatif dan 13 (32,5\%) sampel dengan kadar albumin urin positif. Nilai $\mathrm{p}=0,799$ berarti dalam penelitian ini tidak terdapat hubungan yang bermakna atau signifikan antara umur dengan kadar albumin urin

3. Hubungan jenis kelamin dengan kadar albumin urin pada pasien $\mathrm{PJH}$

Tabel 7 : Hubungan jenis kelamin dengan kadar albumin urin

\begin{tabular}{|c|c|c|c|c|c|c|}
\hline & \multicolumn{2}{|c|}{ Kadar albumin urin } & \multirow{2}{*}{ Total } & \multirow{2}{*}{ Nilai p } & \multirow{2}{*}{$\begin{array}{l}\text { Prediksi } \\
\text { OR }\end{array}$} \\
\hline & & Negatif & Positif & & & \\
\hline \multirow{5}{*}{$\begin{array}{l}\text { Jenis } \\
\text { kelamin }\end{array}$} & \multirow[b]{2}{*}{ Laki-laki } & 6 & 15 & 21 & 0,121 & \multirow{5}{*}{$\begin{array}{l}2,778 \text { pada } \\
\text { ci } 95 \% \\
(0,752- \\
10,260)\end{array}$} \\
\hline & & $15,0 \%$ & $37,5 \%$ & $52,5 \%$ & & \\
\hline & \multirow{2}{*}{ Perempuan } & 10 & 9 & 19 & & \\
\hline & & $25,0 \%$ & $22,5 \%$ & $47,5 \%$ & & \\
\hline & Total & $\begin{array}{l}16 \\
100,0 \%\end{array}$ & $\begin{array}{l}24 \\
100,0 \%\end{array}$ & $\begin{array}{l}40 \\
100,0 \%\end{array}$ & & \\
\hline
\end{tabular}

Dalam tabel 7, menunjukkan bahwa pada sampel laki-laki terdapat $6(15,0 \%)$ orang dengan kadar albumin urin negatif, dan 15 (37,5\%) orang dengan kadar positif, sedangkan pada sampel perempuan terdapat $10(25,0 \%)$ orang dengan kadar albumin urin negatif, sedangkan $9(22,5 \%)$ orang memiliki kadar positif. Nilai $\mathrm{p}=0,121$ berarti dalam penelitian ini tidak terdapat hubungan yang bermakna atau signifikan antara jenis kelamin dengan kadar albumin urin.

\section{PEMBAHASAN}

Hasil penelitian yang di lakukan selama periode November sampai Desember 2012 di poliklinik Jantung, ruang Irina F Jantung, dan CVCU RSUP Prof. dr. R.D. Kandou Manado ditemukan jumlah penderita penyakit jantung hipertensi sebanyak 40 orang yang terdiri dari 20 penderita (50\%) PJH dengan derajat ringan dan 20 penderita $(50 \%) \mathrm{PJH}$ dengan derajat berat. Dimana jenis kelamin dari penderita PJH ini terdiri dari laki-laki 21 (52,5\%) dan perempuan 19 (47,5 \%). Golongan umur dari penderita PJH yang dirawat di RSUP Prof. dr. R.D Kandou Manado dengan kategori usia 40 - 49 tahun tidak terdapat $(0,0 \%)$ sampel yang memiliki kadar albuminuria negatif dan 5 (12,5\%) sampel dengan kadar positif. Pada kategori usia 50 - 59 tahun terdapat 7 (17,5\%) sampel dengan kadar albumin urin negatif dan 6 (15,0\%) sampel dengan kadar albumin urin positif. Pada kategori usia 60 - 70 tahun terdapat 9 (22,5\%) sampel yang dengan kadar albumin urin negatif dan 13 (32,5\%) sampel dengan kadar albumin urin positif.

Dalam penelitian ini dapat dilihat bagaimana hubungan albumin urin dengan penyakit jantung hipertensi pada derajat ringan dan derajat berat, dan hasil yang tunjukkan adalah pada pasien PJH denga derajat ringan (CHF I dan II) yang berjumlah 20 penderita menunjukkan 13 $(65,5 \%)$ kadar albumin urinnya negatif dan 7 (35,5\%) kadar albumin urinnya positif. Sedangkan pada pasien PJH dengan derajat berat (CHF III dan IV) yang berjumlah 20 penderita didapati $3(15,5 \%)$ kadar albumin urin negatif dan $17(85,5 \%)$ penderita dengan kadar albumin urin positif. Pada hasil uji tes Chi square nilai $\mathrm{p}=0,001$. Hal ini berarti terdapat hubungan yang signifikan atau bermakna antara kadar albumin urin dengan penyakit jantung hipertensi pada pasien yang dirawat jalan dan dirawat inap dengan nilai prediksi OR pada CI 95\% $(2,27-48,75)$ ialah 10,52 artinya jika dilakukan penelitian selanjutnya bisa ditemukan bahwa pada penderita penyakit jantung hipertensi dengan derajat ringan berisiko mendapat peningkatkan kadar 
albumin dalam urin sebesar 10,52 kali saat derajat penyakit jantung hipertensi meningkat berdasarkan peningkatan dari klasifikasi gagal jantung yang dialami pasien. Nilai daripada rasio prevalensi yang didapatkan sebesar 4,33.

Hasil penelitian ini sesuai dengan teori yang ada, dimana pada teori mengatakan pada penyakit hipertensi dan penyakit kardiovaskular, albumin urin biasanya menjadi penanda resiko penyakit kardiovaskular. Albumin dapat menjadi target untuk memperoleh proteksi/perlindungan kardiovaskular. ${ }^{9}$ Teori lain juga mengatakan pada gagal jantung kongestif frekuensi relatif kejadian albumin urin sangat sering terjadi yang disebabkan peningkatan volume plasma ${ }^{7}$ yang sesuai pada penelitian dimana kadar albumin urin meningkat pada pasien $\mathrm{PJH}$ dengan derajat berat dibandingakan dengan pasien PJH dengan derajat ringan.

Pada penelitian sebelumnya yang dilakukan Herera dkk, didapatkan hasil bahwa mikroalbuminurina positif memiliki hubungan dengan hipertensi dan penyakit jantung. ${ }^{11}$ Jensen JS dkk, meneliti pada pasien hipertensi dengan mikroalbuminuria meningkat empat kali resiko terjadinya penyakit jantung iskemik dibandingkan normoalbuminuria. ${ }^{12}$ Pada penelitian lainnya tentang hubungan albumin urin dengan hipertrovi ventrikel kiri yang merupakan patofisiologi penyakit jantung hipertensi ditemukan bahwa adanya hubungan kadar albumin urin dengan HVK dan ditemukan bahwa peningkatan kadar albumin urin pada pasien hipertensi dengan HVK dibandingkan dengan pasien hipertensi tanpa HVK. ${ }^{13}$

\section{SIMPULAN}

Berdasarkan hasil analisi dan pembahasan terhadap hasil penelitian yang diperoleh, maka dapat disimpulkan bahwa terdapat perbedaan nilai kadar albumin urin antara kelompok pasien PJH dengan derajat ringan dibandingkan dengan kelompok pasien PJH dengan derajat berat dimana kadar albumin urin lebih tinggi pada kelompok pasien PJH dengan derajat berat daripada kelompok pasien PJH dengan derajat ringan serta adanya hubungan antara ekskresi albumin urin dengan penyakit jantung hipertensi.

\section{UCAPAN TERIMA KASIH}

Ditujukan kepada dr. A. Lucia Panda, SpPD ,SpJP (K) selaku Dosen Pembimbing dan Penguji I, dr. Eko E. Surachmanto, SpPD-KAI selaku Dosen Pembimbing dan Penguji II, dan Prof. Dr. dr. E.Moeis, SpPD-KGH selaku Penguji III serta kepada semua pihak yang baik secara langsung dan tidak langsung telah menumbuhkan ide atau gagasan pada penulis sehingga penulis dapat menyelesaikan artikel ini.

\section{DAFTAR PUSTAKA}

1. Brown CT. Penyakit aterosklerotik koroner. Dalam: Price SA, Wilson LM,editor. PATOFISIOLOGI Konsep Klinis Proses-Proses Penyakit. Vol I. Ed VI. Penerbit Buku Kedokteran EGC, Jakarta. 2006;583

2. Cutler, Jeffrey A., et al. . 2007. Trends in Hypertension Prevalence, Awareness, Treatment, and Control Rates in United States Adults Between 19881994 and 1999 2004. http://hyper.ahajournals.org/cgi/content/full/52/5/818.

3. Departemen Kesehatan RI. Profil kesehatan Indonesia 2008. Jakarta: Departemen Kesehatan RI;2009:29,62 http://www.depkes.go.id 
4. Joesoef, H. Andang, Setianti, Budhi. Hipertensi Sekunder. Dalam: Buku Ajar Kardiologi. Jakarta : FK UI. 2003

5. Riaz K, Ahmed A, Talavera F, Ali YS, Hypertensive Heart Disease. Medscape reference drug, disease and procedure. 2011 available at http://emedicine.medscape.com/article/162449-overview last update 4 Desember 2012.

6. Diamond JA, PhillipsRA. Hypertensive Heart Disease. Hypertens Res Vol. 28, No. 3 (2005). On International journal of obesity. Hypertension research available at http://www.nature.com/hr/journal/v28/n3/abs/hr200525a.html last update 4 Desember 2012.

7. Sacher RA, McPherson RA. Tinjauan Klinis Hasil Pemeriksaan Laboratorium edisi 11, diterjemahkan oleh Pendit BU; Wulandari D. Protein serum dan plasma. Penerbit Buku Kedokteran EGC, Jakarta. 2004;311-9

8. Murray RK, Granner DK, Rodwell VW. Biokimia Harper edisi 27, diterjemahkan oleh Pendit BU; Murray RK. Protein plasma dan imunoglobulin. Penerbit Buku Kedokteran EGC, Jakarta. 2009;608-609

9. Bawazier LA. Proteinuria. Dalam: Sudoyo A, Setiyohadi B, Alwi I, Simadibrata M, Setiati S. Buku Ajar Ilmu Penyakit Dalam. Jilid III. Ed IV. Pusat Penerbitan Ilmu Penyakit Dalam Fakultas Kedokteran Universitas Indonesia. Jakarta. 2006;519-523

10. Herrera R, Almaguer M, Chipi J, Martinez O, Bacallao J, Rodriguez N, et al. Albuminuria as a marker of kidney and cardio-cerebral vaskular damage. MEDICC Review. 2010;12:20-6

11. Jensen JS, Rasmussen BF, Strandgaard S et al. Arterial hypertension, microalbuminuria, and risk of ischemic heart disease. Hypetension. 2000;35:898-903.

12. Nelson E. Hubungan Antara Mikroalbuminuria Yang Dinilai Dengan Rasio Albumin Kreatinin Urin Dengan Hipertrofi Ventrikel Kiri Pada Penderita Hipertensi Esensial. USU Repository. Medan. 2009 